\title{
Analisis Kekuatan Tarik Membran Kitosan Kreco Sebagai Filtrasi Air Konsumsi Rumah Tangga
}

\author{
Ahmad Dony Mutiara Bahtiar1, Nilla Nurlina², Devina Rosa Hendarti ${ }^{3}$ \\ 1,2,3Teknik Mesin, PSDKU Politeknik Negeri Malang Di Kota Kediri \\ Adonbahtiar82@gmail.com
}

\begin{abstract}
Abstrak
Pemanfaaatan limbah cangkang kreco yang selama ini hanya dibuang begitu saja supaya mempunyai nilai lebih yang bermanfaat untuk masyarakat. Kreco salah satu molusca yang hidup bebas di daerah persawahan. Penelitian ini mengusulkan sebuah gagasan baru menggunakan cangkah kreco sebagai membran filtrasi air kran di perumahan dan Uji Tarik erat kaitannya dengan sifat mekanik membran. Parameter ini penting karena menjadi pertimbangan dalam pemilihan membran dalam beberapa aplikasi seperti saringan air ketika mendapatkan tekanan air. Cangkang keong sawah tersebut dicuci dengan larutan asam asetat dan disikat sampai bersih. Kemudian di giling sampai berbentuk serbuk dan mengalami berbagai macam perlakuan sampai terbentuk membran. Dari hasil penelitian didapatkan membran yang memiliki kekuatan Tarik tertinggi adalah ketebalan $6 \mathrm{~mm}$.
\end{abstract}

Kata kunci : Filtrasi, Kitosan, Kreco, Membran, Uji Tarik

\begin{abstract}
Utilization of kreco shell waste which so far has only been thrown away so that it has added value that is beneficial to the community. Kreco is a mollusk that lives freely in rice fields. This research proposes a new idea using kreco-step as an air filtration membrane in housing and Tensile Test is closely related to the mechanical properties of the membrane. This parameter is important because it is considered in the selection of membranes in several applications such as air filters when getting air pressure. The rice snail shells were washed with acetic acid solution and brushed until clean. Then milled to form a powder and subjected to various treatments to form a membrane. From the results of the research, the membrane that has the highest tensile strength is $6 \mathrm{~mm}$ thick.
\end{abstract}

Keywords: Filtration, Chitosan, Kreco, Membrane, Tensile Test

\section{PENDAHULUAN}

Kreco merupakan salah satu hewan molusca yang hidup bebas di daerah persawahan. Pada awalnya kreco hidup sebagai hama tanaman pertanian sekarang justru dibudidayakan sebagai salah satu makanan yang kaya akan protein hewani [1]. Kreco diolah menajadi berbagai macam makanan mulai dari sate kreco, osengoseng kreco, dan semur kreco. Dari hasil olahan kreco tersebut menyisakan sampah cangkang kreco yang belum termanfaatkan dengan baik. Bahkan sampah cangkang kreco menimbulkan berbagai masalah seperti bau dan menumpuk begitu saja yang banyak dihinggapi lalat. 
Cangkang kreco tersusun terdiri dari kalsium fosfat, silikat, magnesium karbonat, besi dan zat organik lainnya membentuk sisa komposisi protein struktural, dan senyawa fosfor [2]. Cangkang kreco merupakan material biopolimer yang selanjutnya dimodifikasi menjadi kitosan melalui proses disetilasi. Kitosan merupakan Kitosan merupakan salah satu produk alam yang merupakan turunan kitin. Kitosan merupakan biopolimer yang didapatkan melalui proses deasetilasi kitin yang mengandung lebih dari 5000 unit glukosamin [3].

Rekayasa membran kitosan diharapkan dapat menghasilkan membran dengan karakter yang lebih baik, misalnya peningkatan kestabilan membrane, memperkecil ukuran poripori membran sehingga pemisahan molekul-molekul atau rejeksi makromolekul dari suatu larutan oleh membran lebih efekti [4]. Melalui uji traik membran harapanya material cangkang kreco mampu memenuhi kualifikasi untuk aterial filtrasi air. Tujuan dari penelitian ini adalah dapat membuat membran dari cangkang Pilla Ampullacea sebagai material membrane serta menganalisis kekuatan tarik membran kitosan kreco terhadap variasi ketebalan $(1,2,3,4,5,6,7,8$ $\mathrm{mm})$.

\section{METODE PENELITIAN}

Penelitian ini menggunakan metode penelitian true eksperimental yaitu penelitian yang sesungguhnya dilaksanakan melalui percobaan, data didapat dari hasil eksperimen di lapangan dengan cara mengambil data secara langsung berdasarkan pengamatan atau observasi terhadap subjek penelitian [5].

\section{A. Bahan Dan Alat}

Bahan yang digunakan antara lain : cangkang kreco, larutan $\mathrm{NaOH}$, aquades, asamasetat, larutan ninhidrin. Sedangkan alat yang digunakan adalah mesin penghancur cangkang kreco, sikat, ayakan 100 mesh, oven, gelas ukur, pipet, cawan petri, pH Meter, corong, thermometer, alat uji tarik.

\section{B. Uji Tarik}

Kekuatan tarik erat kaitannya dengan sifat mekanik membran. Parameter ini penting karena menjadi pertimbangan dalam pemilihan membran dalam beberapa aplikasi seperti saringan air ketika mendapatkan tekanan air. Pengukuran tensile strength, elongation, dan Modulus Young menggunakan merk Shimadzu AGx 690, 
sensitivitas 1/1000, dengan beban maksimum 1 ton, kecepatan minimum $10 \mathrm{~mm} / \mathrm{s}$ dan kecepatan maksimum $25 \mathrm{~mm} / \mathrm{s}$. Membran hasil sintesis yang telah disimpan dalam wadah kedap udara yang berisi silika gel dipotong menyerupai dumbbell seperti pada Gambar 1. Lalu membran diuji kekuatan tarik dengan kecepatan tarik $10 \mathrm{~mm} / \mathrm{menit}$. Ujung sampel dijepit pada alat uji tarik, lalu sampel ditarik sampai putus. Besarnya gaya tarik yang diberikan $(\mathrm{kgF})$ dan perpanjangan membran $(\Delta \mathrm{l})$ dicatat:

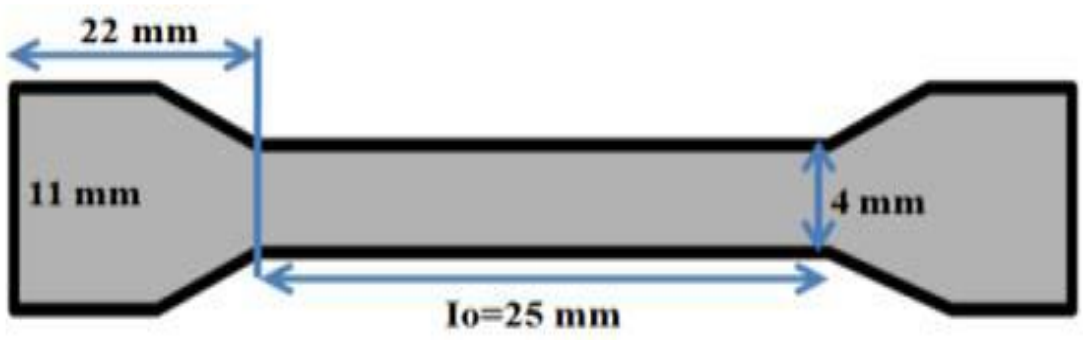

Gambar 1. Bentuk sampel uji tarik

\section{HASIL DAN PEMBAHASAN}

\section{A. Pembuatan Membran}

Cangkang kreco dicuci dengan air bersih untuk menghilangkan kotoran dan sisa daging yang masih menempel pada pangkal cangkang. Kemudian cangkang dikeringkan di bawah sinar matahari untuk menghilangkan kandungan air dan memfasilitasi penyimpanan. Cangkang kering kemudian ditumbuk dan disaring menggunakan ayakan ukuran 100 mesh untuk memperluas area permukaan sehingga proses interaksi sampel dengan pelarut ketika isolasi kitosan lebih efektif. Tujuan dari tahap demineralisasi adalah untuk menghilangkan mineral atau senyawa anorganik yang terkandung dalam cangkang keong. Umumnya mineral yang ditemukan dalam cangkang keong adalah $\mathrm{CaCO}^{3}$ (kalsium karbonat) dan $\mathrm{Ca}^{3}$ (PO4) 2 (kalsium fosfat). Proses penghapusan dilakukan dengan mereaksikan bubuk shell dengan larutan 1,5 M HCl. Pada suhu 60-70 ${ }^{\circ} \mathrm{C}$ sambil disterilkan selama 4 jam. Reaksi yang terjadi adalah sebagai berikut [6]:

$\mathrm{CaCO} 3(\mathrm{~s})+2 \mathrm{HCl}(\mathrm{aq})-->\mathrm{CaCl} 2(\mathrm{aq})+\mathrm{H} 2 \mathrm{O}(\mathrm{l})+\mathrm{CO} 2(\mathrm{~g})$
$\mathrm{Ca} 3(\mathrm{PO} 4) 2(\mathrm{~s})+4 \mathrm{HCl}(\mathrm{aq})-->2 \mathrm{CaCl} 2(\mathrm{aq})+\mathrm{Ca}(\mathrm{H} 2 \mathrm{PO} 4) 2(\mathrm{l})$ 
Menurut reaksi di atas, gas $\mathrm{CO} 2$ yang terbentuk dapat dilihat dengan adanya gelembung dalam proses demineralisasi. Hasil reaksi demineralisasi ini membentuk kitin mentah yang berwarna coklat atau kuning muda. Pada fase deproteinisasi, akan terjadi pemutusan ikatan antara protein dan kitin sehingga warnanya berubah menjadi kuning kecoklatan. Tahap deasetilasi menggunakan 50\% $\mathrm{NaOH}$ solusi yang berfungsi untuk memutuskan ikatan karboksil dengan atom nitrogen dalam kitin. Konsentrasi $\mathrm{NaOH}$ yang tinggi menyebabkan gugus fungsi amino $(-\mathrm{NH} 3+)$ yang menggantikan gugus kitin kitin menjadi lebih aktif sehingga proses deasetilasi menjadi lebih baik. Berikut foto membran yang sudah tercetak
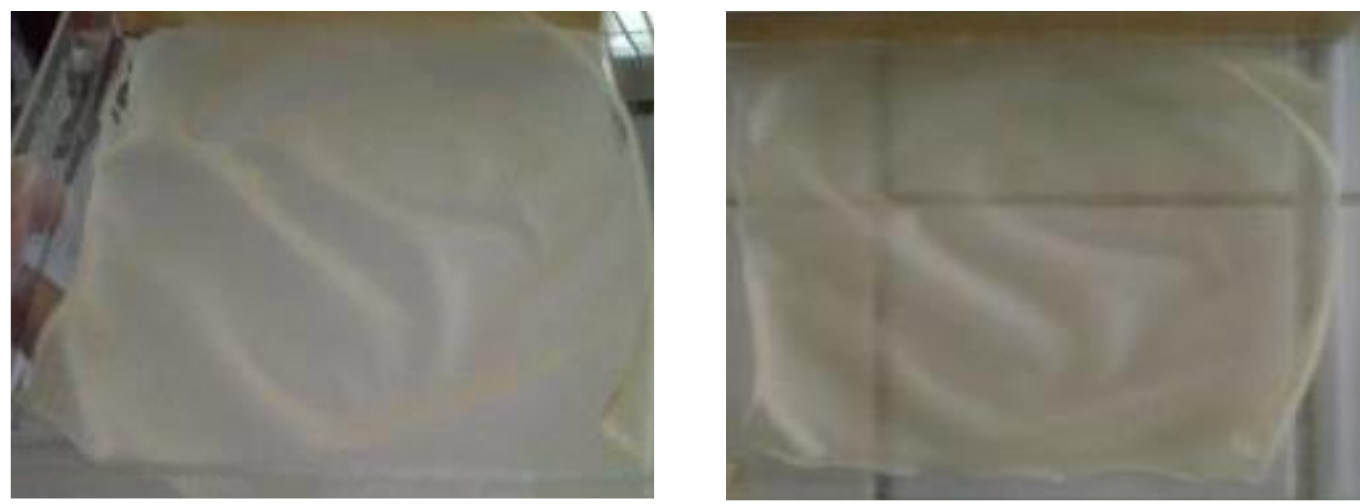

Gambar 2. Membran Kitosan Cangkang Kreco

\section{B. Analisis Kekuatan Tarik Membran Kitosan}

Kekuatan tarik memiliki hubungan yang terikay dengan sifat mekanik membran. Parameter ini penting karena menjadi pertimbangan dalam pemilihan membran dalam beberapa aplikasi seperti filtrasi air. Sifat mekanik membran ini meliputi kekuatan, kekerasan, kekakuan dan elastisitas. Kekuatan mekanik membran kitosan cangkang kreco ditentukan melalui alat uji tarik Shimadzu, dengan kecepatan tarik $10 \mathrm{~mm} / \mathrm{menit}$, pada temparatur ruang.

Dari hasil penelitian menunjukkan bahwa peningkatan ketebalan sampai dengan $6 \mathrm{~mm}$ cenderung meningkatkan kekuatan tarik dan perpanjangan, serta menurunkan Modulus Young. Perpanjangan sebesar 112,0\%, kuat putus 0,180 MPa dan Modulus Young sebesar 14,31 MPa. Namun demikian, pada ketebalan 7 dan $8 \mathrm{~mm}$ kekuatan tarik dan perpanjangan cenderung menurun,serta Modulus Young meningkat secara fisik membran dengan massa kitosan 8 dan $7 \mathrm{~mm}$ hasilnya kurang baik, mudah sobek dan kaku. Hal ini didukung oleh data daya serap air. 
Pada peningkatan ketebalan kitosan $1 \mathrm{~mm}$ sampai $5 \mathrm{~mm}$, pada membran menunjukkan peningkatan kekuatan tarik. Pada saat ketebalan $6 \mathrm{~mm}$ adalah titik tertinggi kekuatan Tarik membran. Akan tetapi pada ketebalan $7 \mathrm{~mm}, 8 \mathrm{~mm}$ pada kondisi tersebut terlihat kecenderungan penurunan sifat mekanik berupa penurunan kuat putus dan perpanjangan serta meningkatnya Modulus Young.

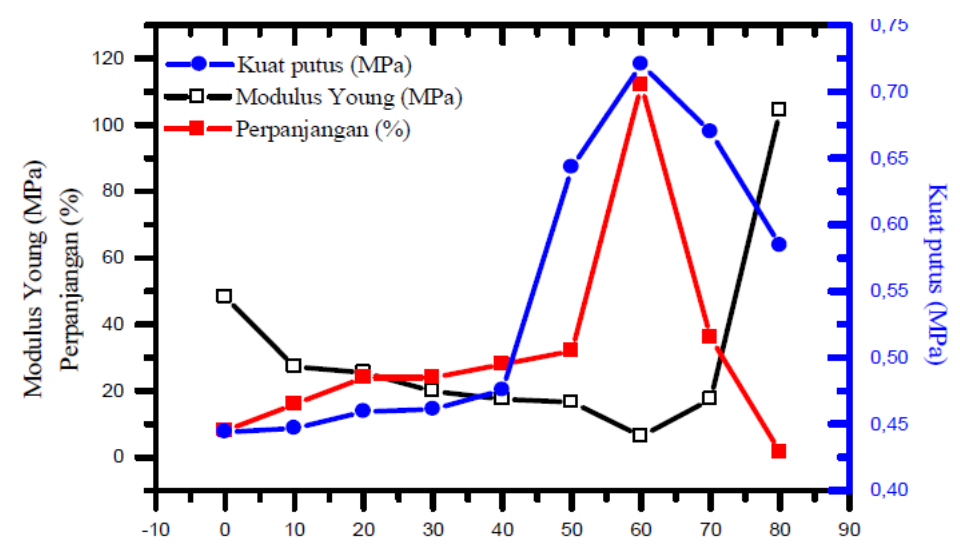

Gambar.3 Kekuatan Tarik Membran

\section{KESIMPULAN}

Analisis membran dari kitosan kreco memiliki kemampuan untuk menyaring air. Kualitas air yang telah bersentuhan dengan membran telah meningkatkan kualitas dan memenuhi persyaratan PERMENKES No. 322017 dalam memberikan kebersihan sanitasi. Kemampuan uji Tarik membran tertinggi pada ketebalan $6 \mathrm{~mm}$ dengan kekuatan Tarik 120 Mpa.

\section{UCAPAN TERIMA KASIH}

Terimakasih kepada pihak Politeknik Negeri Malang atas dana DIPA Penelitian Swadana Reguler Kompetisi kontrak No. Nomor: SP DIPA-023.18.2.677606/2021.

\section{Daftar Pustaka}

[1] E. D. Ratnasari, "Anjuran Ahli Gizi Saat Makan Keong Sawah untuk Sumber Protein," cnnindonesia, $07 \quad 12$ 2017. [Online]. Available: 
https://www.cnnindonesia.com/gaya-hidup/20171207103634-255-

260745/anjuran-ahli-gizi-saat-makan-keong-sawah-untuk-sumber-protein.

[2] R. R. Syariffudin, "PENGARUH PENGGUNAAN SERBUK CANGKANG KEONG SAWAH SEBAGAI SUBSTITUSI PARSIAL SEMEN TERHADAP NILAI MODULUS ELASTISITAS," Jurnal Sipil Statik, vol. 8, no. 5, pp. 655664, 2020.

[3] M. Nitsae, H. Solle and M. Ledo, "Preparasi Kitosan dari Cangkang Keong Sawah (Pila ampullacea) Asal Persawahan 'Aerbauk' Desa Oesao, Kabupaten Kupang untuk Adsorpsi Timbal (II)," Jurnal MIPA, vol. 41, no. 2, pp. 96-104, 2018.

[4] S. Yunianti and D. K. Maharani, "PEMANFAATAN MEMBRAN KITOSANSILIKA UNTUK MENURUNKAN KADAR ION LOGAM PB(II) DALAM LARUTAN," UNESA Journal of Chemistry, vol. 1, no. 1, pp. 108-115, 2021.

[5] N. S. Sukmadinata, Metode Penelitian Pendidikan, Bandung: PT. Remaja Rosdakarya, 2008.

[6] Vogel, Teks Analisis Anorganik Kualitatif Makro dan Semimikro. edisi ke lima, Jakarta: Kalman Media Pustaka, 1985. 